\title{
Employee Turnover in Manufacturing SMEs in Japan: An Analysis of the Link with HRM Practices
}

\section{Aruna S. Gamage}

Department of Human Resource Management, Faculty of Management, University of Sri Jayewardenepura, Sri Lanka. arunasgamage@gmail. com

\begin{abstract}
Small and Medium Enterprise (SME) sector is playing a significant role in Japanese economy. However, over the last two decades, SMEs have no longer been a thriving source of growth. The firm entry rate has downward trend while exit rate has trended upward in recent years and considerably exceeded the entry rate. One of the reasons for the high rate of business failures in SMEs, is due to its less attention to the human side of their businesses when compared with their counter parts of large enterprises. High voluntary turnover is considered to be the one of critical problem for SME owner/managers among many other human resource issues. Therefore, the objective of this paper is to examine the relationship between Human Resource Management (HRM) practices and voluntary turnover in SMEs in Japan. Specifically, this study attempts to examine the relationship between HRM practices and voluntary turnover shedding some lights on the mediating effect of the link in between HRM practices and turnover rate. A structured questionnaire was developed and sent to 436 SMEs in Aichi Prefecture and 144 firms responded to the questionnaire resulting in 32 percent response rate. Based on the data analysis it was found that there is negative but weak relationship, partially mediated by HR outcomes, between HRM practices and voluntary turnover rate in manufacturing SMEs in Japan.
\end{abstract}

Keywords: human resource management, small and medium enterprises, HRM outcomes, labour turnover.

\section{Introduction}

Small and Medium Enterprise (SME) sector contributes more than fifty percent to its GDP in Japan, the third largest economy in the world. The importance SME sector is often indicated not only by the very large share of the GDP they occupy but also, the number of companies, total number of employees, value of shipments etc. There are 4.69 million SMEs in Japan, constituting 99.7\% of all enterprises, accounting for $70 \%$ of all employment (Small and Medium Enterprise Agency, 2013). Therefore, this sector is considered to be the backbone of their economy. Although their relative importance as a share of the number of enterprises and the number of employees is declining compared with the situation at the beginning of the 2000 s, there is no change in the fact 
that the SME sector still accounts for the vast majority of enterprises and employees in Japan. The majority of products of LEs are made up of parts produced by SME subcontractors, and therefore, the reliability of Japanese products is supported by the underlying strength of SMEs. SMEs also play a major role in revitalizing the local economy and increasing employment opportunities (Sato, 2013).

However, over the last two decades, SMEs have no longer been a thriving source of growth. The profitability and investment of SMEs have declined significantly and business registration of SMEs has been in the decline. The number of manufacturing establishments employing four to 299 people steadily declined from 434,754 in 1985 to 254,675 in 2007(METI, 2006). The sharp decline in the number of establishments was caused not only by the abolishment of enterprises but also by the lower number of enterprises entering the economy. As shown in Figure 1, the entry rate has experienced a prolonged decline since the 1970s. The firm exit rate has trended upward in recent years, and rose by a record annual average of $6.0 \%$ (based on the number of enterprises) between 2001 and 2004(METI, 2006). As a consequence, the firm exit rate has considerably exceeded the firm entry rate despite the slight upward swing in the entry rate (METI, 2006).

However, successful business management of SMEs largely depends on the quality of human resource that supports companies (JASMEC, 2001). Securing and retaining high quality personnel are, therefore, key factors for the growth of SMEs, which often have limited opportunities to utilize managerial resources. But, it is argued that Japanese SMEs are paying less attention to HRM practices when compared with their counter parts of large enterprises (JASMEC, 2001). Therefore, the prime objective of this study is to examine the relationship of HRM practices and voluntary labour turnover in manufacturing SMEs in Japan shedding some lights on the mediating link in between these two.

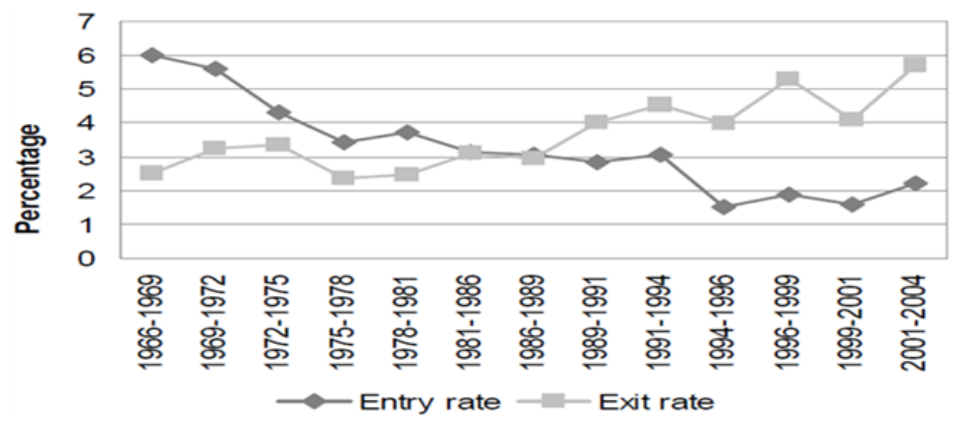

Figure 1: Trends in Entry and Exit Rates of SMEs in Japan 


\section{HRM In SMEs}

\section{Literature Review}

In this section an overview of research on HRM in SMEs is presented and subsequently, briefly presents main conclusions of studies which have been conducted on the relationship between HRM practices and voluntary labour turnover within SME business context.

Human resources are the most critical factor for the success of any business firm irrespective of their size, nature and other characteristics. Given the importance of SMEs employees to the national economy, however, scholars are lamenting over the dearth of information in SME research given to the study of human resource management practices. No matter where you look, in surveys (Hornsby and Kuratko, 1990), in reviews of literature (Good, 1998), and in empirical studies (Heneman and Berkley, 1999), scant attention has been given to the studies of human resource management practices in SMEs. Proper management of a company's human resources is the key to business survival in today's highly competitive world. The organizational effectiveness of the firm (Huselid, 1995; Terpstra and Rozell, 1993) and its ability to create a sustainable competitive advantage (Prahalad, 1983; Pfeffer, 1994) can hinge on whether HRM practices are properly thought out and successfully implemented.

The human potentials in a company are generally much more difficult for competitors to duplicate than the plant, equipment or even products that a company produces (Flanagan and Despanade, 1996). Consequently, the nature and well being of a company's employees can become its main strength in carving out a profitable existence in the industry. HRM practices can be particularly important for small firms (Marlow and Patton, 1993) since they tend to be so dependent on human capital. Research indicates that inadequate and insufficient management of employees in small firms has resulted in low productivity and high labour turnover rates (Mathis and Jackson, 1991) and is one of the leading causes of small business failures (McEvoy, 1984).

The overall goal of human resource management is to ensure that the company will be able to achieve success through people. HRM aims to increase the effectiveness and organizational skills, which means the ability of an organization to achieve its goals using the available resources in the best way possible. Some authors in their studies have found that HRM systems can be the source of firms' organizational capabilities that allow one to learn and benefit from new opportunities. 


\section{HRM and Employee Turnover}

With the publication of the first comprehensive empirical analysis and measurement of the costs of labor turnover in 1913, the interest in the labor turnover problem increased (Bruce, 2005). Turnover is the rotation of workers around the labour market; between firms, jobs, and occupations; and between the states of employment and unemployment (Abassi and Hollman, 2000). When employees leave a company and have to be replaced, that's called turnover (Bruce, 2005). A certain amount of turnover is unavoidable, but too much can ruin a company. Some employees will always retire, move away, go back to universities and colleges, leave the country, or leave the workforce. This level of turnover is not only unavoidable but can be beneficial to a certain extent. It gives the opportunity to bring new blood into the organization with new ideas and a fresh perspective.

Firms that dedicate significant resources to attract, develop, and motivate qualified people do not want to see them leave soon after, especially in a tight labor market (Cascio, 2000). The consequences of such departures are well documented, in terms of disruptions to the normal operations of an organization and lower organizational performance (Huselid 1995; Kacmar et al., 2006). Having understood this fact very well, some business managers have designed retention programs that include generous employee benefits, flexible work arrangements, career development opportunities, and a host of other initiatives that are intended to retain their good performers.

There are two types of turnover and they are voluntary and involuntary. When the employee chooses to leave for whatever reason, it is called voluntary turnover. Involuntary turnover is the layoffs and similar actions where the decision for an employee to leave is made by the company. However, voluntary turnover is the measure used to discuss and compare employers in general business setting as it is the most directly affected type by the front line supervisors. It often results in departing employees migrating to competing firms, creating an even more critical situation since this knowledge can now be used against the organization.

Voluntary turnover has in fact been accelerating over the past decade as recent studies have shown that employees on average switch employers in every six years. This situation signals senior management to consider the repercussions of voluntary turnover, and immediately create contingent plans. While functional turnover (i.e. bad performers leave, good performers stay) can help reduce sub-optimal organizational performance (Johnson et al., 2000), excessive turnover can be detrimental to the firm's productivity jeopardizing the realization of the firm's long term goals and objectives. Unfortunately, despite employee turnover being such a serious problem, scholars are lamenting over the dearth of studies investigating it; especially studies using a comprehensive set of causal variables are rare. 
Literature review evidences that some scholars have tried to rectify the situation. In one such study Chang and Chang (2008), state that effective human resource practices such as education and training, a performance acknowledgement system, communication, authorisation, and power were able to lower the intention of employees to leave the organization. Chew and Chan (2008) stressed that training and development as well as remuneration and recognition showed positive relationships with the intention to stay in the organisation. Move over, Govaerts et al. (2011) emphasized that talented employees are willing to continue working in the organization if the management implements an appreciative learning and working climate.

Employee turnover is giving sleepless nights especially to human resource managers in many countries around the world. A widely-held belief is that employees have developed bad attitudes due to their own reasons including perceived labor shortage. Employees are believed to job-hop for no reason or even for fun. However, some researchers and managers assume that peoplecentered human resources practices will cut down on employee turnover, but the scientific results have been mixed. Based on the data from the Canadian government's Workplace and Employee Survey (WES), University of Montreal researchers examined out 14 specific practices and compared them to the likelihood of people quitting their jobs. For the purpose of this study, 4,160 workplaces with 10 employees or more were included, from a broad range of industries. Workplace practices in 1999 were compared to voluntary turnover in 2000, suggesting (though not proving) that the practices affected the turnover rates (Haines and Larose, 2010). However, the biggest surprise to some readers may be that training was linked to a higher likelihood of someone quitting. The authors, citing previous studies, say this may be because increased skills make it easier for a worker to find a job in another company (Haines and Larose, 2010).

Many researchers hold the position that employees leave their jobs when their needs are not being satisfied by their present job and an alternative job becomes available. According to Huselid's (1995) extensive survey of literature, perceptions of HR practices such as job security and compensation level are important determinants of employee turnover. As same that, the negative relationship between working conditions and voluntary turnover has received attention from many researchers (Gupta and Jenkins, 1991) indicating the propensity of employees quitting their jobs when working conditions are not conducive. In a study conducted by Saiyadain and Ahmad (1997) on Malaysia found that 90 percent and 68 percent of workers in the private and public estates, respectively, indicated that what they hated most is poor working conditions in their estates.

HR practices such as pay, benefits and training are negatively related to turnover because they motivate employees to stay within the organization 
(Madrian, 1994; Gruber and Madrian, 1994). Drawing from their conclusion, it is intuitive to assume that organizations with substantial training opportunities will have lower voluntary turnover rates. The foregoing shows that HR practices seem to be negatively associated with voluntary turnover. Therefore, training can play a significant role increasing employee's ability, motivations and reducing job stress of employees thereby increasing the propensity to stay with the organization further.

However, so far so few studies have addressed organizational variables such as human resource management practices in their studies conducted especially in SMEs. Therefore, the focus of the present study here is on specific human resource management practices, many of which have seldom or have never been investigated in relation to voluntary turnover rates in SMEs contexts. Although many studies have clustered two distinct classifications i.e. voluntary and involuntary, this study is aiming to examine voluntary turnover specifically.

\section{Operationalisation of Variables}

\section{Human Resource Management Practices}

Human Resource Management (HRM) is the effective and efficient utilization of human resources to achieve organizational objectives (Opatha, 2010). HRM is the human side of the organizational management. It is mostly responsible for the recruitment, selection, training, assessment, and rewarding of employees for getting maximum contribution toward the organizational success. Stone (2005) defined human resource management as productive use of people in achieving the organization's strategic business objectives and the satisfaction of individual employees. The effective use of HRM practices is able to link these practices with organization's goals and objectives. The importance of these practices may differ from firm to firm. One of the most comprehensive and widely used measures for human resource practice was presented by Dessler (2008) and Fisher et al. (2006). In their studies, human resource management practices are characterized as multidimensional, and it has four major facets namely; staffing, training \& development, employee performance evaluation, and compensation of employees.

\section{Staffing}

Staffing is the process of acquiring, deploying, and retaining a workforce of sufficient quantity and quality to create positive impacts on the organization's effectiveness. It involves recruitment, selection, hiring and induction of potential employees. Recruitment is the process of finding and attracting suitably qualified people to apply for job vacancies in the organization. It is 
a set of activities an organization uses to attract job candidates who have the needed abilities and attitudes. Selection is the process of making the choice of the most appropriate person from the pool of applicants recruited to fill the relevant job vacancy. Hiring is the process appointing selected candidates to the posts which are vacant. Induction is said to be the HRM function that systematically and formally introduces the new employee to the organization, to the job, to the work group to which new employee will belong and the work environment where the new comer will work. Various tools and techniques are used by firms for the improvement of staffing process to avoid the loss in terms of time, money and potential employees.

\section{Training \& Development}

Training \& development is another dimension of human resource practices where firms invest on development of their employees' knowledge, skills, ability and other required skills to improve the productivity of employees. Training \& Development is the HRM function that formally and systematically provides new learning to increase employees' capabilities. The primary purpose of training \& development is to increase organizational performance by increasing employee performance. Training \& development can transform human resource to human capital where skilled employee would better perform in the success of organization as compared with none or less- trained employees.

\section{Performance Evaluation}

Performance evaluation is defined as the systematic process of identifying, measuring, influencing, and developing job performance of the employees in the organization in relation to the set of norms and standards for a particular period of time in order to achieve various purposes (Opatha, 2010).This aspect of human resource practices generally involves the activities of various evaluation designs, both formal and informal, and different evaluation periodicities (Shub \& Stonebraker, 2009). It is a means of getting better results by understanding and managing performance within an agreed framework of planned goals, standards and competency requirements. It functions as a continuous and evolutionary process, in which performance improves over time. Moreover, it provides the basis for regular and frequent dialogues between managers and individuals about performance and development needs (Armstrong, 2006).

\section{Compensation Management}

Compensation is the total amount of the monetary and non-monetary pay provided to an employee by an employer in return for work performed as 
required. It is one of the most extrinsic practices of human resource function in an organizational setting. Compensation may include payments such as bonuses, profit sharing, overtime pay, recognition rewards, and sales commissions etc. Compensation can also include non-monetary perks such as a company-paid car, stock options in certain instances, company-paid housing, and other non-monetary items. This dimension determines the level of job of an employee on the basis of their perceived knowledge and experience. Moreover, the matching of their job knowledge with the pay or compensation provided them must demonstrate the market level competitive packages. Good compensation plan would therefore, inevitably influence on employees' performance. However, the extent to which an employee who is getting the good compensation package will perform well would also depend on his or her overall assessment of various factors like the compensation package in other organizations in relation to the work load and the possibility of getting better compensation packages (Purani \& Sahadev, 2008).

\section{Operational Performance (OP) - Voluntary Labour Turnover}

Operational performances are those related to the goals of an organizational operation, including productivity, product quality, new product development, customer satisfaction, and employee retention. However, in this study, employees' retention or, to put it another way, lower voluntary labour turnover is considered as the operational performance. Drawing from conclusions of previous studies it is assumed an existence of negative correlation between HRM practices and voluntary labour turnover in manufacturing SMEs in Japan. This relationship is, it is assumed, mediated by nine HR outcomes; knowledge quality (KQ), occupational health and safety (OHS), job satisfaction (JS), employee commitment (EC), employee attitudes (EA), employee motivation (EM), employee loyalty (EL), employee involvement (EI)), and workplace cooperation (WC).

\section{Conceptual Framework}

For the purpose of this study, four (4) HRM practices namely; employee staffing, training \& development, performance of the management, compensation management were selected. Then, the relationship between HRM practices and labour turnover was examined exploring the mediating relationship of nine foregoing HR outcomes. Based on the above theoretical underpinnings, a conceptual frame for the study was constructed as in Figure 2. According to the model in Figure 2, effective application of HRM practices first generate HR outcomes and then these HR outcomes in turn give rise to lower the voluntary labour turnover. The model further goes on explaining the link through which HRM practices are mediating with organizational performance. 


\section{Methodology}

Selected HRM practices were considered as the independent variables and voluntary labour turnover was treated as the dependent variable while HR outcomes were taken as the mediating variables of the study. A structured questionnaire was developed as the main data collection instrument. Four (04) different HRM practices were selected for the study. There were; employee staffing, training \& development, performance management, compensation management. These four HRM practices were the most widely discussed HRM practices in the literature. In order to examine the HRM intensification, forty (40) items (employee staffing-10; training \& development-12; and performance management-10, and Compensation management- 8) were included in the questionnaire. Nine (9) HR outcomes; knowledge quality (KQ), occupational health and safety (OHS), job satisfaction (JS), employee commitment (EC), employee attitudes (EA) employee motivation (EM), employee loyalty (EL), employee involvement (EI)), and workplace cooperation (WC) were considered as the mediating variables for the study. Exact figures in labour turnover were used to measure the dependent variable. The questionnaire was first developed in English and then translated into Japanese to make respondents better understand it.

Four hundred thirty six (436) questionnaires were distributed to a randomly selected sample of manufacturing SMEs in Nagoya in Aichi Prefecture. An electronic data file maintained by the Nagoya Chamber of Commerce was used to draw the sample. One hundred five (105), equivalents to thirty two percent (32 percent), responded to the survey. Data was analyzed by using SPSS version 16. Descriptive statistics were used to understand the characteristics of firms and person product movement correlation coefficient was used to examine the relationships among variables.

\section{Reliability and Validity of the Questionnaire}

In order to measure the reliability of instruments, Cronbach's alpha coefficient is widely used. According to Sekaran (2005), if the alpha value is greater 0.7, the instrument is said to be acceptable. The internal consistency reliability coefficients (Cronbach's alpha) for the scales used in this study are well above the level of 0.7. Table 1 shows coefficients for all variables. According to the table 1, each variable has got more than 0.8 alpha values which are well above the norms and thus are acceptable for the analysis purpose. Validation procedures involved initial consultations with subject matter experts about the questionnaire prepared. The experts also judged the face and content validity of the questionnaire and decided as adequate. Hence, the researcher was satisfied with the reliability and validity of the scale. 


\begin{tabular}{|l|c|}
\hline \multicolumn{1}{|c|}{ Variable } & Cronbach Alpha \\
\hline Employee Staffing (10) & 0.916 \\
\hline Training and Development (12) & 0.941 \\
\hline Performance Evaluation (10) & 0.939 \\
\hline Compensation Management (8) & 0.871 \\
\hline HRM Outcomes (18) & 0.921 \\
\hline
\end{tabular}

Table 1: Reliability Analysis

Source: Survey Data, 2013

\section{Results}

\section{HRM Practices, HR Outcomes and Voluntary Turnover}

Table 2 shows Pearson product movement correlation coefficients among HRM practices, HR outcomes and voluntary turnover. According to the table 2, all most all HRM practices are negatively correlated with voluntary labour turnover. However, these correlations are not strong and statistically significant. First, employee staffing shows negative correlation with labour turnover. This relationship is weak and not statistically significant $(r=-.160)$. Second, the correlation of training \& development with labour turnover is also negative and not strong and statistically significant $(\mathrm{r}=-.176)$. Third, performance evaluation function also establishes weak correlation $(\mathrm{r}=-.122)$. This relation is also negative and not statistically significant. Finally, the relationship in between compensation management and labour turnover is also negative but weak $(\mathrm{r}=-.130)$. In order to examine the mediating relationship in between HRM practices and labour turnover, HR outcomes were studied. Based on the nine HR outcomes, a cumulative index that represents the aggregation of all nine HR outcomes was developed. The links between HRM practices and HR outcome index were examined. Not surprisingly with earlier studies, this study too establishes very strong positive correlations in between all four HRM practices and HR outcomes, (Employee staffing, $r=.458, \mathrm{p}<$ 0.01; Training \&development, $\mathrm{r}=.462, \mathrm{p}<0.01$; performance evaluation, $\mathrm{r}=$ $.483, \mathrm{p}<0.01$; and compensation management, $\mathrm{r}=.406, \mathrm{p}<0.01$ ). However, the correlation of HR outcome index and labor turnover is negative. It is weak and not statistically significant $(\mathrm{r}=-.133)$. 


\begin{tabular}{|l|c|c|c|c|c|}
\hline \multicolumn{7}{|c|}{ Correlations among variables } \\
\hline Variable & ES & TD & PE & CM & HROC \\
\hline $\begin{array}{l}\text { Employee Staffing } \\
\text { (ES) }\end{array}$ & 1 & & & & \\
\hline $\begin{array}{l}\text { Training and } \\
\text { Development (TD) }\end{array}$ & $.794 * *$ & & & & \\
\hline $\begin{array}{l}\text { Performance } \\
\text { Evaluation (PE) }\end{array}$ & $.702 * *$ & $.632 * *$ & & & \\
\hline $\begin{array}{l}\text { Compensation } \\
\text { Management (CM) }\end{array}$ & $.600 * *$ & $.581 * *$ & $.724 * *$ & & \\
\hline $\begin{array}{l}\text { HR Outcomes } \\
\text { (HROC) }\end{array}$ & $.458 * *$ & $.462 * *$ & $.483 * *$ & $.406 * *$ & \\
\hline $\begin{array}{l}\text { Voluntary Turnover } \\
\text { (VT) }\end{array}$ & -.160 & -.176 & -.122 & -.130 & -.133 \\
\hline
\end{tabular}

Table 2: Correlations among variables

Source: Survey Data, 2013

\section{Discussion}

\section{HRM Practices and Voluntary Labour Turnover}

This study focused on four major aspects of HRM practices and their relationships with labour turnover. In contrast with the findings of previous studies in large organizations, this study establishes very weak but negative correlation of HRM practices with labour turnover in manufacturing SMEs in Japan. According to the findings of the study, all four HRM practices were weakly but negatively correlated with labour turnover. It implies the idea that four HRM practices; employee staffing, training \& development, performance management, and compensation management are having negative and weak relations with labour turnover. The negative correlation highlights the fact that an increase of the usage of foregoing HRM practices gives rise to lower voluntary labour turnover. As all these relations are negative, with the increase of the usage of the said HRM practices, labour turnover will be increased. However, the weak magnitude implies that the influence of HRM practices on labour turnover is minimal in manufacturing SMEs in Japan. Although this study confirms the finding of earlier studies, the established negative relation is so weak. The reason for these weak relations, as the author infers, is due to the nature of so called life-long employment system (now being referred to as relatively long term) in Japanese business culture. One of the dominant characteristic of Japanese style HRM is its life-long employment system. It means that when a new employee is hired to the organization, there is a psychological bond between the employer and employee that the new 
employee will work for the company until his or her mandatory retirement age. This element in their HRM style is now changing but still the characteristic of relatively longer term employment system can be seen even now. Therefore, the author believes that HRM practices do not have much influential power to change their long established cultural based behaviors.

Analysis of the data establishes weak but negative correlation of HR outcomes with labor turnover. Therefore, it is intuitive to assume that HR outcomes are playing a mediating relationship in between HRM practices and labour turnover. With this correlation, it is reasonable to assume that an increase of the usage of above HRM practices give rise to lower labour turnover through HR outcomes. Although the magnitude is low, drawn upon these findings, it can be concluded that those owners/mangers in SMEs who are concerned about employee retention should focus on effective use of HRM practices prescribed above. However, in order to examine the impact of mediating effect of HR outcomes further analysis with sophisticated statistical techniques is needed in need.

\section{Iplications, Limitations and Directions for Future Reseach}

The results of this study offer several key theoretical and practical implications for SMEs owners and managers interested in improving business performance of their SMEs. This study confirmed the fact that effective HRM practices lead to positive HR outcomes even for SMEs. The effective use HR practices; employee staffing, training \& development, performance management, and compensation management in SMEs was shown to be related to HR outcomes which represented by knowledge quality, occupational health and safety, job satisfaction, employee commitment, employee attitudes, employee motivation, employee loyalty, employee involvement and workplace cooperation. These positive HR outcomes in turn are translated into positive operational performance such as decrease in voluntary labour turnover. This highlights the fact that HRM practices do matter even for SMEs and are shown to have links with operational performance like lower voluntary turnover rate in their businesses. Therefore, as the study highlights, when evaluating many options that are available to SMEs, it is very important to keep in mind not to discount the importance human resource management.

This study is subject to certain limitations encountered in the research process. The study was based on the data collected only from 136 manufacturing SMEs in Aichi prefecture in Japan. Therefore, generalisability could have been increased if number of sufficient manufacturing firms representing all of the prefectures in Japan were taken. Further, this study focused only on the relationship, not the effect or impact, between HRM practices and labor turnover. However, the value of the study could have been much more if this study could focus on the effect of HRM practices on labour turnover too. 
However, future research with relatively larger samples expanding to other sectors in SMEs is suggested to bridge this information gap.

\section{References}

Abassi, S. M. \& Hollman K.W. (2000). Turnover: the real bottom line, public and voluntary turnover in the workplace: A comparison of companies across industries. Thesis prepared for the degree of Master of Science, August, 2007. 1- 49. Retrieved from: http://www. google.com.

Armstrong, M. (2006). A Handbook of Human Resource Management Practice, 10th ed., London: Kogan Page.

Bruce, K. (2005). The Economists and the issue of labour turnover. Business History, 47(4): 493-510.

Cascio, W. F. (2000). Costing human resources: The financial impact of behavior in organizations. Cincinnati: South-Western.

Chang, C. P. \& Chang, W. C. (2008). Internal marketing practices and employees' turnover intentions in tourism and leisure hotels. The Journal of Human Resource and Adult Learning, 4(2): 161-172.

Chew, J. \& Chan, C. C. A. (2008). Human resource practices, organizational commitment and intention to stay. International Journal of Manpower, 29(6): 503-522.

Dessler, G. (2008). Human Resource Management, 11th ed., NJ: Pearson Prentice-Hall, Upper Saddle River.

Fisher, C. D. Schoenfeldt, L. F. \& Shaw, J. B. (2006). Human Resource Management, 6th ed., Boston, MA: Houghton Mifflin.

Flangan D. S. \& Despande, S. P. (1996). Top management's perceptions of changes in HRM practices after union elections in small firms, Journal of Small Business Management, 34(4): 23-34.

Good, D. C. (1998). Gender and successful human resource decision in small business, New York, Garland publishing, Blackpool.

Govaerts, N., Kyndt, E., Dochy, F., \& Baert, H. (2011). Influence of learning and working climate on the retention of talented employees. Journal of Workplace Learning, 23(1): 35-55.

Gruber, J., \& Madrian, B. C. (1994). Health insurance and job mobility: The effects of public policy on job-lock. Industrial and Labor Relations Review, 48 (1):86-102. 
Gupta, N., \& Jenkins, G. D. (1980). The structure of withdrawal: Relationships among estrangement, tardiness, absenteeism and turnover. Springfield, VA: National Technical Information Service.

Honsby, J. S, \& Kuratko, D.K. (1990). Human resource management in small business: critical issues for the 1990s, Journal of Small Business Management, 28(July): 9-18.

Huselid, A. M. (1995). The impact of human resource management practices on turnover, productivity, and corporate financial performance. Academy of Management Journal, 38 (3): 635-672.

JASMEC, (2001). Role of Japanese SMEs: What is SMEs? Tokyo.

Kransdorff, A. (1996). Succession planning in a fast-changing world. Management Decision, 34(2):30-34.

Johnson, J., Griffeth, R.W., \& Griffin, M. (2000). Factors discrimination functional and dysfunctional sales force turnover. Journal of Business and Industrial Marketing, 15(6): 399-415.

Kacmar, K. M., Martha, C. A., David, L. V. R., Chris, S., \& Stephen, C. (2006). Sure everyone can be replaced...but at what cost? Turnover as a predictor of unit-level performance. Academy of Management Journal, 49(1): 133-144.

Madrian, B. C. (1994). Employment-based health insurance and job mobility: Is there evidence of job-lock? Quarterly Journal of Economics, 109(February): 27-51.

Marlow, S., \& Patton, D. (1993). Managing the employment relationship in the small firm: Possibilities for human resource management. International Small Business Journal, 11(4): 57-64.

Mathis, R., \& Jakson, J. (1991). Personnel/Human resource management, 6th ed. St Paul, Minn: West Publishing.

McEvoy, M. G. (1984). Small business personnel practices. Journal of Small Business Management, 22(4): 1-8.

McEvoy, Glenn M., \& Wayne F. C. (1987). Do good or poor performers leave? A meta-analysis of the relationship between performance and turn-over. Academy of Management Journal, 30(4): 744-62.

METI, (2006). White paper on SMEs in Japan 2006, Japan Small Business Research Institute: Tokyo.

OECD, (2002). Management Training in SMEs, Retrieved from www.oecd. org/pdf. 
Opatha, H.H.D.N.P. (2010). Human resource management, Author published, Colombo

Purani, K. and Sahadev, S. (2008). The moderating role of industrial experience in the job satisfaction, intention to leave relationship: an empirical study among salesmen in India. Journal of Business and Industrial Marketing, 23(7): 475-485.

Saiyadain, M. S., \& Ahmad, Z. A. (1997). Human resource management in Malaysian oil palm estates. Unpublished project report, Universiti Sains Malaysia, Pulau Pinang. In A. B. Muhammad \& J. Muhammad (2005). Human resource practices as determinants of employee turnover: an empirical investigation. Asian Academy of Management Journal, 10(2):69-80.

Sato, K. (2013). Japan's Policies for Small and Medium Enterprises. Economic Attache Embassy of Japan in the KSA: KSA.

Sekaran, U. (2005). Research Methods for Business: A Skill Building Approach, John Wiley \& Sons.

Shub, A. N. \& Stonebraker, P. W. (2009). The Human Impact on Supply Chains: Evaluating the Importance of "Soft" Areas on Integration and Performance, Supply Chain Management: An International Journal, 14(1): 31-40.

SMEs Agency, (2013). Contribution of SMEs to the national economy of Japan. Retrieved from http://www.chusho.meti.go.jp/sme_english

Stone, R. J. (2005). Human Resource Management, 5th ed., Australia: John Wiley \& Sons.

Terpstra, E. D., \& Rozell, J. E. (1993). The relationship of staffing practices to organizational level measures of performance Personnel Psychology, 46 (1): $27-48$. 